\title{
Cost-Effectiveness Analysis of the Residential Provisions of the 2015 IECC for Nebraska
}

\section{February 2016}

\author{
VV Mendon \\ M Zhao \\ ZT Taylor \\ E Poehlman
}




\title{
DISCLAIMER
}

This report was prepared as an account of work sponsored by an agency of the United States Government. Neither the United States Government nor any agency thereof, nor Battelle Memorial Institute, nor any of their employees, makes any warranty, express or implied, or assumes any legal liability or responsibility for the accuracy, completeness, or usefulness of any information, apparatus, product, or process diselosed, or represents that its use would not infringe privately owned rights. Reference herein to any specific commercial product, process, or service by trade name, trademark, manufacturer, or otherwise does not necessarily constitute or imply its endorsement, recommendation, or favoring by the United States Government or any agency thereof, or Battelle Memorial Institute. The views and opinions of authors expressed herein do not necessarily state or reflect those of the United States Government or any agency thereof.

\author{
PACIFIC NORTHWEST NATIONAL LABORATORY \\ operated by \\ BATTELLE \\ for the \\ UNITED STATES DEPARTMENT OF ENERGY \\ under Contract DE-AC05-76RL01830 \\ Printed in the United States of America \\ Available to DOE and DOE contractors from the \\ Office of Scientific and Technical Information, \\ P.O. Box 62, Oak Ridge, TN 37831-0062; \\ ph: (865) 576-8401 \\ fax: (865) 576-5728 \\ email: reports@adonis.osti.gov \\ Available to the public from the National Technical Information Service, \\ U.S. Department of Commerce, 5285 Port Royal Rd., Springfield, VA 22161 \\ ph: (800) 553-6847 \\ fax: $(703) 605-6900$ \\ email: orders@ntis.fedworld.gov \\ online ordering: http://www.ntis.gov/ordering.htm
}

This document was printed on recycled paper.

$(9 / 2003)$ 


\title{
Cost-Effectiveness Analysis of the Residential Provisions of the 2015 IECC for Nebraska
}

\author{
VV Mendon \\ M Zhao \\ ZT Taylor \\ E Poehlman
}

February 2016

Prepared for

the U.S. Department of Energy

under Contract DE-AC05-76RL01830

Pacific Northwest National Laboratory

Richland, Washington 99352 
*Authors' Note

The present report is a revision of a previous report of the same name published in October 2015. The previous report was revised to update numbers reported in certain results tables. 


\section{Acronyms and Abbreviations}

$\mathrm{BC} 3$

BECP

CPI

DOE

EIA

ERI

ICC

IECC

LCC

NAHB

PNNL
Building Component Cost Community

Building Energy Codes Program

Consumer Price Index

U.S. Department of Energy

Energy Information Administration

Energy Rating Index

International Code Council

International Energy Conservation Code

Life-Cycle Cost

National Association of Home Builders

Pacific Northwest National Laboratory 


\section{Highlights}

\section{The 2015 IECC provides cost-effective savings for residential buildings in Nebraska. Moving to the 2015 IECC from the 2009 IECC base code is cost- effective for residential buildings in all climate zones in Nebraska.}

The average statewide economic impact (per dwelling unit) of upgrading to the 2015 IECC is shown in the table below based on typical cost-effectiveness metrics. ${ }^{1}$

\begin{tabular}{||l|c|}
\hline \multicolumn{1}{|c|}{ Metric } & Compared to the 2009 IECC \\
\hline \hline $\begin{array}{l}\text { Life-cycle cost savings of the 2015 } \\
\text { IECC }\end{array}$ & $\$ 6490.29$ \\
\hline $\begin{array}{l}\text { Simple payback period of the 2015 } \\
\text { IECC }\end{array}$ & 2.9 years \\
\hline $\begin{array}{l}\text { Net annual consumer cash flow in } \\
\text { year 1 of the 2015 IECC }\end{array}$ & $\$ 362.14$ \\
\hline $\begin{array}{l}\text { Annual (first year) energy cost } \\
\text { savings of the 2015 IECC }(\$)\end{array}$ & $\$ 427.81$ \\
\hline $\begin{array}{l}\text { Annual (first year) energy cost } \\
\text { savings of the 2015 IECC }(\%)\end{array}$ & $21.5 \%$ \\
\hline
\end{tabular}

\footnotetext{
${ }^{1} \mathrm{~A}$ weighted average is calculated across all climate zones in the state.

${ }^{2}$ The annual cash flow is defined as the net difference between annual energy savings and annual cash outlays (mortgage payments, etc.), including all tax effects but excluding up-front costs (mortgage down payment, loan fees, etc). First-year net cash flow is reported; subsequent years' cash flow will differ due to the effects of inflation and fuel price escalation, changing income tax effects as the mortgage interest payments decline, etc.
} 
PNNL-24968 Rev-1

\section{Cost-Effectiveness Results for the 2015 IECC for Nebraska}

This section summarizes the cost-effectiveness analysis in terms of three primary economic metrics:

- Life-Cycle Cost (LCC): Full accounting over a 30-year period of the cost savings, considering energy savings, the initial investment financed through increased mortgage costs, tax impacts, and residual values of energy efficiency measures

- Consumer Cash Flow: Net annual cost outlay (i.e., difference between annual energy cost savings and increased annual costs for mortgage payments, etc.)

- Simple Payback Period: Number of years required for energy cost savings to exceed the incremental first costs of a new code, ignoring inflation and fuel price escalation rates

LCC savings is the primary metric used by the U.S. Department of Energy (DOE) to assess the economic impact of residential building energy codes. Simple payback period and the Consumer Cash Flow analysis are reported to provide additional information to stakeholders. Both the LCC savings and the year-by-year cash flow values from which it is calculated assume that initial costs are mortgaged, that homeowners take advantage of mortgage interest tax deductions, that individual efficiency measures are replaced with like measures at the end of their useful lifetimes, and that efficiency measures may retain a residual value at the end of the 30 -year analysis period.

\section{Life-Cycle Cost}

The Life-Cycle Cost (LCC) analysis computes overall cost savings per dwelling unit resulting from implementing the efficiency improvements of a new energy code. LCC savings are based on the net change in overall cash flows (energy savings minus additional costs) resulting from implementing a new energy code. LCC savings are summed over an analysis period of 30 years. Future cash flows are discounted to "present values" using a discount rate that accounts for the changing value of money over time. LCC savings is the economic metric used by DOE for decision making purposes.

Table 1 shows the LCC savings (discounted present value) over the 30-year analysis period for the 2015 IECC compared to the 2009 IECC.

Table 1. Life-Cycle Cost Savings of the 2015 IECC compared to the 2009 IECC

\begin{tabular}{|c|c|}
\hline \hline Climate Zone & Life-Cycle Cost Savings (\$) \\
\hline \hline 5A & $\$ 6,490.29$ \\
\hline
\end{tabular}

\section{Consumer Cash Flow}

The Consumer Cash Flow results are derived from the year-by-year calculations that underlie the Life-Cycle Cost savings values shown above. The specific cash flow values shown here allow an assessment of how annual cost outlays are compensated by annual energy savings and the time required 
for cumulative energy savings to exceed cumulative costs, including both increased mortgage payments and the down payment and other up-front costs.

Table 2 shows the per-dwelling-unit impact of the improvements in the 2015 IECC on Consumer Cash Flow compared to the 2009 IECC.

Table 2. Consumer Cash Flow from Compliance with the 2015 IECC Compared to the 2009 IECC

\begin{tabular}{||c|c|c||}
\hline & Cost/Benefit & 5A \\
\hline A & $\begin{array}{c}\text { Down payment and other } \\
\text { up-front costs }\end{array}$ & $\$ 118.73$ \\
\hline B & $\begin{array}{c}\text { Annual energy savings } \\
\text { (year one) }\end{array}$ & $\$ 427.81$ \\
\hline C & Annual mortgage increase & $\$ 65.31$ \\
\hline D & $\begin{array}{c}\text { Net annual cost of } \\
\text { mortgage interest } \\
\text { deductions, mortgage } \\
\text { insurance, and property } \\
\text { taxes (year one) }\end{array}$ & $\$ 0.37$ \\
\hline $\begin{array}{c}\text { E } \\
=\end{array}$ & $\begin{array}{c}\text { Net annual cash flow } \\
\text { savings (year one) }\end{array}$ & $\$ 362.14$ \\
[B-(C+D)] & $\begin{array}{c}\text { Years to positive savings, } \\
\text { including up-front cost } \\
\text { impacts }\end{array}$ & 0.33 \\
\hline $\begin{array}{c}\text { F } \\
= \\
\text { [A/E] }\end{array}$ & $\begin{array}{c}\text { implest } \\
\text { Note: Item D includes mortgage interest deductions, } \\
\text { mortgage insurance, and property taxes for the first } \\
\text { year. Deductions can partially or completely offset } \\
\text { insurance and tax costs. As such, the "net" result } \\
\text { appears relatively small or is sometimes even negative. }\end{array}$ \\
\hline
\end{tabular}

\section{Simple Payback Period}

The simple payback period is a straightforward metric including only the costs and benefits directly related to the implementation of energy-saving measures associated with a code change. It represents the number of years required for the energy savings to pay for the cost of the measures, without regard for changes in fuel prices, tax effects, measure replacements, resale values, etc. The simple payback period is useful for its ease of calculation and understandability. Because it focuses on the two primary characterizations of a code change - cost and energy performance - it allows an assessment of cost effectiveness that is easy to compare with other investment options and requires a minimum of input data. DOE reports the simple payback period because it is a familiar metric used in many contexts. However, because it ignores many of the longer-term factors in the economic performance of an energy-efficiency investment, DOE does not use the payback period as a primary indicator of cost effectiveness for its own decision-making purposes. 
Table 3 shows the simple payback period for the 2015 IECC for Nebraska. The simple payback period is calculated by dividing the incremental construction cost by the first-year energy cost savings assuming time-zero fuel prices. It estimates the number of years required for the energy cost savings to pay back the incremental cost investment without consideration of financing of the initial costs through a mortgage, the favored tax treatment of mortgages, the useful lifetimes of individual efficiency measures, or future escalation of fuel prices.

Table 3. Simple Payback Period for the 2015 IECC Compared to the 2009 IECC

\begin{tabular}{|c|c|}
\hline \hline Climate Zone & Payback Period (Years) \\
\hline \hline 5A & 2.9 \\
\hline
\end{tabular}


PNNL-24968 Rev-1

\section{Overview of the Cost-Effectiveness Analysis Methodology}

This analysis was conducted by Pacific Northwest National Laboratory (PNNL) in support of the U.S. Department of Energy's (DOE) Building Energy Codes Program. DOE supports the development and implementation of energy efficient and cost-effective residential and commercial building energy codes. These codes help adopting states and localities establish minimum requirements for energy-efficient building design and construction, as well as ensure significant energy savings and avoided greenhouse gas emissions.

The present analysis evaluates the cost-effectiveness of the prescriptive path of the 2015 edition of the International Energy Conservation Code (IECC), relative to the 2009 IECC. The analysis covers one- and two-family dwelling units, town-homes, and low-rise multifamily residential buildings covered by the residential provisions of the 2015 IECC. The IECC's simulated performance path and the new Energy Rating Index (ERI) path included in the 2015 IECC are not in the scope of this analysis due to the large variety of building configurations those paths allow. While buildings complying via these paths are generally considered to provide equal or better savings compared to the prescriptive requirements, the intent of these paths is to provide additional design flexibility at a cost dictated by the builder or homeowner. DOE has established a methodology for determining energy savings and cost-effectiveness of various residential building energy codes (Taylor et al. 2012). The LCC analysis described in that methodology balances upfront costs with longer term consumer savings and is therefore DOE's primary economic metric for its decision making processes.

\section{Estimation of Energy Usage and Savings}

In order to estimate the energy impact of residential code changes, PNNL developed a single-family prototype building and a low-rise multifamily prototype building to represent typical new residential building construction (BECP 2012, Mendon et al. 2013 and Mendon et al. 2014). The key characteristics of these prototypes are described below:

- Single-Family Prototype: A two-story home with a $30-\mathrm{ft}$ by $40-\mathrm{ft}$ rectangular shape, $2,400 \mathrm{ft}^{2}$ of $^{-}$ conditioned floor area excluding the basement (if any), and window area equal to $15 \%$ of the conditioned floor area equally distributed toward the four cardinal directions.

- Multifamily Prototype: A three-story building with 18 units ( 6 units per floor), each unit having conditioned floor area of $1,200 \mathrm{ft}^{2}$ and window area equal to approximately $23 \%$ of the exterior wall area (not including breezeway walls) equally distributed toward the four cardinal directions.

These two building prototypes are further expanded to cover four common heating systems (natural gas furnace, heat pump, electric resistance and oil-fired furnace), and four common foundation types (slab-on-grade, heated basement, unheated basement, crawlspace), leading to an expanded set of 32 residential prototype building models. This set is used to simulate the energy usage for typical homes built to comply with the requirements of the 2015 IECC and those built to comply with the requirements of the 2009 IECC for one location in each climate zone in the state using DOE's EnergyPlus ${ }^{\mathrm{TM}}$ software, version 8.0 (DOE 2013). A detailed discussion of the code provisions considered in this analysis is given by Mendon et. al. (2013 and 2015). Energy savings of the 2015 IECC relative to the 2009 IECC, 
including space heating, space cooling, water heating and lighting, are extracted from the simulation results.

\section{Fuel Prices}

The energy savings from the simulation analysis are converted to energy cost savings using the most recent state-specific residential fuel prices from DOE's Energy Information Administration (EIA 2014a, EIA 2014b, EIA 2014c). The fuel prices used in the analysis are shown in Table 4.

Table 4. Fuel Prices used in the Analysis

\begin{tabular}{|c|c|c||}
\hline $\begin{array}{c}\text { Electricity } \\
(\$ / \mathbf{k W h})\end{array}$ & $\begin{array}{c}\text { Gas } \\
(\$ / \text { Therm })\end{array}$ & $\begin{array}{c}\text { Oil } \\
(\$ / M B t u)\end{array}$ \\
\hline \hline$\$ 0.11$ & $\$ 1.15$ & $\$ 19.01$ \\
\hline
\end{tabular}

\section{Financial and Economic Parameters}

The financial and economic parameters used in calculating the LCC and annual consumer cash flow are based on the latest DOE cost-effectiveness methodology (Taylor et al. 2015) to represent the current economic scenario. The parameters are summarized in Table 5 for reference.

Table 5. Economic Parameters used in the Analysis

\begin{tabular}{||c|c||}
\hline Parameter & Value \\
\hline \hline Mortgage interest rate (fixed rate) & $5.00 \%$ \\
\hline Loan fees & $0.6 \%$ of the mortgage amount \\
\hline Loan term & 30 years \\
\hline Down payment & $10 \%$ of home value \\
\hline Nominal discount rate (equal to mortgage rate) & $5.00 \%$ \\
\hline Inflation rate & $1.60 \%$ \\
\hline Marginal federal income tax & $15 \%$ \\
\hline Marginal state income tax & $6.84 \%$ \\
\hline Property tax & $1.10 \%$ \\
\hline
\end{tabular}

\section{Aggregation Scheme}

Energy results, weighted by foundation and heating system type, are provided at the state level and separately for each climate zone within the state. The distribution of heating systems for Nebraska is derived from data collected by the National Association of Home Builders data (NAHB 2009) and is 
summarized in Table 6. The distribution of foundation types is derived from the Residential Energy Consumption Survey data (EIA 2009) and is summarized in Table 7. The single-family and multifamily results are combined for each climate zone in the state and the climate zone results are combined to calculate a weighted average for the state using housing starts from the 2010 U.S. Census data (Census 2010). The distribution of single- and multifamily building starts is summarized in Table 8 .

Table 6. Heating Equipment Shares

\begin{tabular}{||c|c|c||}
\hline \multirow{2}{*}{ Heating System } & \multicolumn{2}{|c||}{ Share of New Homes (percent) } \\
\cline { 2 - 3 } & Single-Family & Multifamily \\
\hline Natural Gas & 57 & 68 \\
\hline Heat Pump & 40 & 25 \\
\hline Electric Resistance & 3 & 4 \\
\hline Oil & 0 & 3 \\
\hline
\end{tabular}

Table 7. Foundation Type Shares

\begin{tabular}{|c|c|c|c|c|}
\hline Foundation Type & Slab-on-grade & Heated Basement & $\begin{array}{c}\text { Unheated } \\
\text { Basement }\end{array}$ & Crawlspace \\
\hline \hline Share of New Homes (percent) & 30 & 33 & 15 & 23 \\
\hline \hline
\end{tabular}

Table 8. Construction by Building Type and Climate Zone

\begin{tabular}{||c|c|c||}
\hline \multirow{2}{*}{ Climate Zone } & \multicolumn{2}{|c|}{ Share of New Homes (percent) } \\
\cline { 2 - 3 } & Single-Family & Multifamily \\
\hline $5 \mathrm{~A}$ & 100 & 100 \\
\hline
\end{tabular}




\section{Incremental Construction Costs}

In order to evaluate the cost-effectiveness of the changes introduced by the 2015 IECC over the 2009 IECC, PNNL estimated the incremental construction costs associated with these changes. For this analysis, cost data sources consulted by PNNL include:

- Building Component Cost Community (BC3) data repository (DOE 2012)

- Construction cost data collected by Faithful+Gould under contract with PNNL (Faithful + Gould 2012)

- RS Means Residential Cost Data (RSMeans 2012)

- National Residential Efficiency Measures Database (NREL 2014)

- Price data from nationally recognized home supply stores

The consumer price index (CPI) is used to adjust cost data from earlier years to the study year (BLS 2015). The estimated costs of implementing the prescriptive provisions of the 2012 IECC over the 2009 IECC are taken from an earlier PNNL study that evaluated the cost-effectiveness of the 2012 IECC (Lucas et al. 2012). The additional costs of implementing the prescriptive provisions of the 2015 IECC over the 2012 IECC are taken from the National 2015 IECC Cost-Effectiveness study (Mendon et.al. 2015). The national scope costs from those studies are adjusted to reflect local construction costs in Nebraska using location factors provided by Faithful+Gould (2011).

Table 9 and Table 10 show the incremental construction costs associated with the 2015 IECC compared to the 2009 IECC for an individual dwelling unit. Table 9 shows results for a house and Table 10 shows results for an apartment or condominium. These have been adjusted using a construction cost multiplier, 0.905 , to reflect local construction costs in Nebraska based on location factors provided by Faithful + Gould (2011).

Table 9. Total Construction Cost Increase for the 2015 IECC Compared to the 2009 IECC (\$)

\begin{tabular}{|c|c|c|c|c||}
\hline & \multicolumn{4}{|c|}{ Single-family Prototype House } \\
\hline \hline Climate Zone & Crawlspace & Heated Basement & Slab & Unheated Basement \\
\hline 5A & $\$ 1,449.10$ & $\$ 1,687.05$ & $\$ 1,491.65$ & $\$ 1,449.10$ \\
\hline
\end{tabular}


PNNL-24968 Rev-1

Table 10. Total Construction Cost Increase for the 2015 IECC Compared to the 2009 IECC $(\$)^{1}$

\begin{tabular}{|c|c|c|c|c||}
\hline & \multicolumn{4}{|c|}{ Multifamily Prototype Apartment/Condo } \\
\hline \hline Climate Zone & Crawlspace & Heated Basement & Slab & Unheated Basement \\
\hline 5A & $\$ 819.90$ & $\$ 854.42$ & $\$ 819.90$ & $\$ 819.90$ \\
\hline
\end{tabular}

\footnotetext{
${ }^{1}$ In the multifamily prototype model, the heated basement is added to the building, and not to the individual apartments. The incremental cost associated with heated basements is divided among all apartments equally.
} 


\section{Energy Cost Savings}

Table 11 shows the estimated annual per-dwelling unit energy costs of end uses regulated by the IECC, which comprise heating, cooling, water heating, and lighting, that result from meeting the requirements of the 2015 and the 2009 IECC.

Table 11. Annual (First Year) Energy Costs for the 2015 IECC and the 2009 IECC

\begin{tabular}{|c|c|c|c|c|c|c|c|c|c|c|}
\hline \multirow[b]{2}{*}{ Climate Zone } & \multicolumn{5}{|c|}{2015 IECC } & \multicolumn{5}{|c|}{2009 IECC } \\
\hline & Heating & Cooling & $\begin{array}{c}\text { Water } \\
\text { Heating }\end{array}$ & Lighting & Total & Heating & Cooling & $\begin{array}{c}\text { Water } \\
\text { Heating }\end{array}$ & Lighting & Total \\
\hline $5 \mathrm{~A}$ & $\begin{array}{l}\$ 569.59 \\
(-40.1 \%)\end{array}$ & $\begin{array}{l}\$ 275.05 \\
(-8.4 \%)\end{array}$ & $\begin{array}{l}\$ 270.35 \\
(-1.2 \%)\end{array}$ & $\begin{array}{l}\$ 130.66 \\
(-11.8 \%)\end{array}$ & $\begin{array}{l}\$ 1245.65 \\
(-25.6 \%)\end{array}$ & $\$ 951.31$ & $\$ 300.37$ & $\$ 273.59$ & $\$ 148.20$ & $\$ 1,673.46$ \\
\hline
\end{tabular}

Table 12 shows the first year energy cost savings as both a net dollar savings and as a percentage of the total regulated end use energy costs. Results are weighted by single- and multifamily housing starts, foundation type, and heating system type.

Table 12. Total Energy Cost Savings (First Year) for the 2015 IECC Compared to the 2009 IECC

\begin{tabular}{||c|c|c||}
\hline Climate Zone & First Year Energy Cost Savings & $\begin{array}{c}\text { First Year Energy Cost Savings } \\
\text { (percent) }\end{array}$ \\
\hline \hline $5 \mathrm{~A}$ & $\$ 427.81$ & 21.5 \\
\hline
\end{tabular}


PNNL-24968 Rev-1

\section{References}

BECP. 2012. Residential Prototype Building Models developed by DOE's Building Energy Codes Program. Available at http://www.energycodes.gov/development/residential/iecc_models/

BLS. 2015. CPI Detailed Report - Data for January 2015, Table 24. U.S. Department of Labor, Bureau of Labor Statistics, Washington, D.C. Available at http://www.bls.gov/cpi/cpid1501.pdf

Census. 2010. Characteristics of New Housing. U.S. Census Bureau, Washington, D.C. Available at http://www.census.gov/construction/chars/completed.html

DOE. 2012. Building Component Cost Community. U.S. Department of Energy, Washington, D.C. Available at http://bc3.pnnl.gov/

DOE. 2013. EnergyPlus Energy Simulation Software, Version 8.0. U.S. Department of Energy, Washington, D.C. Available at http://apps1.eere.energy.gov/buildings/EnergyPlus/

DOE. 2015. Determination Regarding Energy Efficiency Improvements in the 2015 International Energy Conservation Code (IECC). U.S. Department of Energy, Washington, D.C. Available at http://www.energycodes.gov/sites/default/files/documents/2015_IECC_Determination.pdf

EIA. 2009. 2009 Residential Energy Consumption Survey Data, HC8.1. U.S. Energy Information Administration, Washington DC. Available at http://www.eia.gov/consumption/residential/data/2009/

EIA. 2014a. Natural Gas Monthly. U.S. Energy Information Administration, Washington, D.C. Available at http://www.eia.gov/dnav/ng/ng pri sum a EPG0 PRS DMcf a.htm

EIA. 2014b. Electric Power Monthly. U.S. Energy Information Administration, Washington, D.C. Available at http://www.eia.gov/electricity/monthly/epm_table_grapher.cfm?t=epmt_5_6_a

EIA. 2014c. Petroleum Marketing Monthly. U.S. Energy Information Administration. Washington, D.C. Available at http://www.eia.gov/petroleum/marketing/monthly/

Faithful + Gould. 2011. Residential Energy Efficiency Measures: Location Factors. Faithful+Gould for Pacific Northwest National Laboratory. Available at http://bc3.pnnl.gov/sites/default/files/Location_Factors_Report.pdf

Faithful + Gould. 2012. Residential Energy Efficiency Measures: Prototype Estimate and Cost Data. Faithful+Gould for Pacific Northwest National Laboratory. Available at http://bc3.pnnl.gov/sites/default/files/Residential_Report.pdf

ICC. 2014. 2015 International Energy Conservation Code. International Code Council, Washington, D.C. Available at http://codes.iccsafe.org/app/book/toc/2015/I-

Codes/2015\%20IECC\%20HTML/index.html

Lucas RG, ZT Taylor, VV Mendon and SG Goel. 2012. National Energy and Cost Savings for New Single- and Multifamily Homes: A Comparison of the 2006, 2009 and 2012 Editions of the IECC. Pacific 
Northwest National Laboratory, Richland, Washington. Available at https://www.energycodes.gov/sites/default/files/documents/NationalResidentialCostEffectiveness.pdf

Mendon VV, RG Lucas and SG Goel. 2013. Cost-Effectiveness Analysis of the 2009 and 2012 IECC Residential Provisions - Technical Support Document. Pacific Northwest National Laboratory, Richland, Washington. Available at http://www.energycodes.gov/sites/default/files/documents/State_CostEffectiveness_TSD_Final.pdf

Mendon VV and ZT Taylor. 2014. Development of Residential Prototype Building Models and Analysis System for Large-Scale Energy Efficiency Studies Using EnergyPlus. 2014 ASHRAE/IBPSA-USA Building Simulation Conference, Atlanta, GA.

Mendon VV, ZT Taylor, SU Rao and YL Xie. 2015. 2015 IECC: Energy Savings Analysis. Pacific Northwest National Laboratory, Richland, Washington. Available at http://www.energycodes.gov/sites/default/files/documents/2015_IECC_FinalDeterminationAnalysis.pdf

Mendon VV, A Selvacanabady, M Zhao and ZT Taylor. 2015. National Cost-Effectiveness of the Residential Provisions of the 2015 IECC. Pacific Northwest National Laboratory, Richland, Washington. Available at https://www.energycodes.gov/sites/default/files/documents/2015IECC CE Residential.pdf

NREL. 2014. National Residential Efficiency Measures Database. National Renewable Energy

Laboratory, Golden, Colorado. Available at http://www.nrel.gov/ap/retrofits/

NAHB. 2009. Builder Practices Reports. National Association of Home Builders, Upper Marlboro, Maryland. Available at http://www.homeinnovation.com/trends_and_reports/data/new_construction

RSMeans. 2015. 2015 RS Means Residential Cost Data. Construction Publishers \& Consultants. Norwell, MA. Available at http://www.rsmeans.com/

Taylor ZT, N Fernandez, and RG Lucas. 2012. Methodology for Evaluating Cost-Effectiveness of Residential Energy Code Changes. Pacific Northwest National Laboratory, Richland, Washington. Available at http://www.energycodes.gov/sites/default/files/documents/residential_methodology.pdf

Taylor ZT, VV Mendon, and N Fernandez. 2015. Methodology for Evaluating Cost-Effectiveness of Residential Energy Code Changes. Pacific Northwest National Laboratory, Richland, Washington. Available at https://www.energycodes.gov/sites/default/files/documents/residential_methodology_2015.pdf 


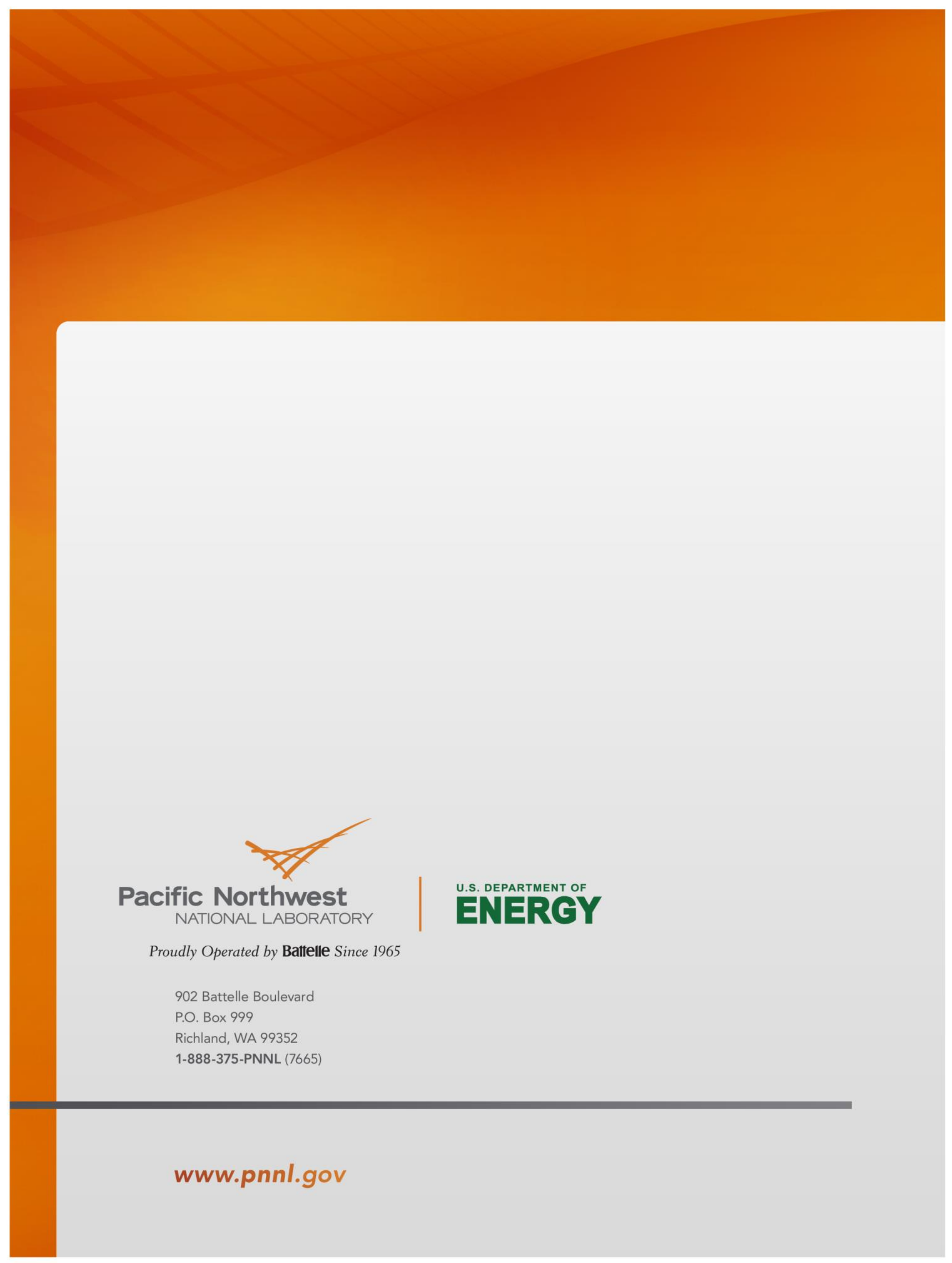

